Journal of Food Science and Technology, vol. 57, 2020, pp. 1601-1608.

\title{
Microplastics: an emerging threat to food security and human health.
}

\section{De-la-Torre, Gabriel Enrique.}

Cita:

De-la-Torre, Gabriel Enrique (2020). Microplastics: an emerging threat to food security and human health. Journal of Food Science and Technology, 57, 1601-1608.

Dirección estable: https://www.aacademica.org/gabriel.e.delatorre/6 ARK: https://n2t.net/ark:/13683/podQ/qNz

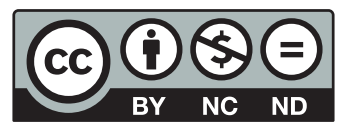




\title{
Microplastics: an emerging threat to food security and human health
}

\author{
Gabriel Enrique De-la-Torre ${ }^{1}$ (B)
}

Revised: 5 September 2019/Accepted: 16 October 2019

(C) Association of Food Scientists \& Technologists (India) 2019

\begin{abstract}
Microplastic presence in seafood and foodstuff have been documented globally in recent studies. Consequently, human exposure to microplastics through the ingestion of contaminated food is inevitable and pose a risk to food security and human health. In this review, microplastics and related xenobiotics are defined, global evidence of microplastic pollution in seafood is reviewed, the impacts to commercial marine species and food security are discussed, and the current knowledge of its direct effects on human health is reviewed. In addition, limited information regarding food security and scientific gaps are identified. Although microplastics in the marine environment and its effects on marine organisms have been well documented, more research is needed to completely understand the implications of microplastics over food security and human health. Further research must focus on monitoring and eliminating microplastics along the food supply chain and determining the extent to which food security is affected by microplastic pollution.
\end{abstract}

Keywords Microplastic - Food security - Human health · Seafood $\cdot$ Food contamination

\section{Introduction}

Plastics are synthetic organic polymers created by the process of polymerisation of monomers extracted from hydrocarbons (Rios et al. 2007). The annual production of plastic products in 2016 reached $>335$ million tons

Gabriel Enrique De-la-Torre

Gabriel.e.dltp@gmail.com

1 Universidad San Ignacio de Loyola, Lima, Peru worldwide (PlasticsEurope 2018). As a consequence, plastics are ubiquitous in modern days (Hitchcock and Mitrovic 2019) and thus, are one of the most common and persistent pollutants to date. Plastic debris enters the oceans in many ways and constantly accumulates in marine environments (Ryan et al. 2009). These pollutants are known for many detrimental impacts such as entanglement, ingestion, effects on reproduction, and translocation of non-native species (Derraik 2002). The sea-based sources of plastic (shipping or fishing) are lower than land-based sources (industries, riverine, tourism and urbanization) in comparison (Andrady 2011). Hence, larger coastal cities produce larger plastic marine pollution.

While the impact that large plastic waste has on the marine environment has been the subject of research for a long time (Cole et al. 2011), microplastic pollution has gained attention by scientists and public perception in the last decade. Microplastics are generally defined as small plastic pieces smaller than $5 \mathrm{~mm}$ in diameter (Andrady 2017) and can be primary or secondary. Primary microplastics are manufactured to be of a microscopic size (Cole et al. 2011), including preproduction resin pellets, microbeads in cosmetics, toothpaste and blasting, powders for textile coatings, and drug delivery media (Shim et al. 2018), while secondary microplastics derive from the degradation of larger plastics (GESAMP 2016) due to photolytic, mechanical fragmentation and biological degradation (Browne et al. 2009), including plastic fragments, microfibers from fabric and rope, coatings, and debris from tire wear (Shim et al. 2018). Microplastics are known to adsorb chemical pollutants in trace concentrations, such as heavy metals, polycyclic aromatic hydrocarbons (PAH), polychlorinated biphenyls (PCB), organochlorine pesticides (OCP), and pharmaceuticals (Brennecke et al. 2016; Camacho et al. 2019; Li et al. 
2018c; Rochman et al. 2014) and leach industrial additives, like polybrominated diphenyl ethers (PBDEs), used as brominated flame retardants, lead heat stabilizers and phthalate plasticizers (Halden 2010; Lithner et al. 2011), resulting in a cocktail of contaminants (Rochman 2015). Due to their small size and spatial distribution in the marine environment, microplastics are highly bioavailable for many organisms. Ingestion of microplastics by marine animals has been widely reported in fish (Kumar et al. 2018; Pegado et al. 2018), bivalves ( $\mathrm{Li}$ et al. 2018a; Su et al. 2018), and mammals (Bravo et al. 2013) sampled from the marine environment.

Although the distribution and effects of microplastics on the environment have been researched, the presence of microplastics in food and the implications for human health are still to be investigated. Fish and shellfish consumption can have health benefits due to their high protein content, omega fatty acids, nutrients and minimum saturated fats (Arts et al. 2001; Pieniak et al. 2010). However, marine food is highly susceptible to xenobiotics and emerging contaminants from the environment (Thompson and Darwish 2019). As for now, studies have reported the presence of microplastics in commercial shellfish from markets (Cho et al. 2019; Li et al. 2018b), canned fish (Karami et al. 2018), drinking mineral water (Schymanski et al. 2018), table salts (Renzi and Blašković 2018), honey and sugar (Liebezeit and Liebezeit 2013). Akhbarizadeh et al. (2018) found microplastics in the muscles of benthic and pelagic fish species from the Persian Gulf. Accordingly, microplastic uptake by commercial fish species should be considered as a potential pathway to human consumption.

The effects of microplastics on human health and how it compromises food security requires further research. For this reason, the aim of this review is to evidence the presence of microplastics in food and explain its implications to food security and potential risks to human health.

\section{Microplastic presence in food}

The increasing global concern about microplastic aquatic pollution is leading to an extensive number of studies assessing microplastics in the past years (Wang and Wang 2018), but researchers have recently focused on its implications to food security and human health. Many commercially relevant fish and shellfish species have been reported to be contaminated with microplastics. Ory et al. (2017) reported that $80 \%$ of the sampled Decapterus muroadsi (Carangidae) from the coast of Rapa Nui, in the South Pacific subtropical gyre, had ingested microplastics very similar to its natural prey, thus indicating one important pathway for microplastics to enter the food chain. Baalkhuyur et al. (2018) assessed microplastic ingestion in 26 different fish species from different habitats from the Saudi Arabian Red Sea coast. Microplastics were found in $14.6 \%$ of the sampled fish, and the highest concentration of ingested microplastics was observed in Parascolopsis eriomma, a species feeding on benthic invertebrates (Baalkhuyur et al. 2018). Concerning bivalves, Van Cauwenberghe and Janssen (2014) evidenced the presence of microplastics in two commercially grown bivalves, Mytilus edulis and Crassostrea gigas, containing an average of $0.36 \pm 0.07$ particles/g and $0.47 \pm 0.16$ particles/g respectively. These results indicate that European shellfish consumers can eat up to 11,000 microplastics annually (Van Cauwenberghe and Janssen 2014). A research on cultured oysters from the coast of China found that $84 \%$ of the sampled oysters were contaminated with microplastics, with an average of 0.62 particles/g (Teng et al. 2019).

Although scientists have focused on the presence of microplastics in organisms sampled from the environment, very few studies have reported microplastics in seafood species coming directly from markets and supermarkets (e.g. Cho et al. 2019; De Witte et al. 2014; Li et al. 2015, 2018b; Rochman et al. 2015; Van Cauwenberghe and Janssen 2014). Li et al. (2015) investigated microplastic pollution in nine commercial bivalves from a fishery market in China. Their results indicate that all the bivalve species had breathed microplastics with concentrations ranging from 2.1 to 10.5 particles/g, being Scapharca subcrenata the species with the highest concentrations $(\mathrm{Li}$ et al. 2015). Li et al. (2018b) also investigated the mussel Mytilus edulis from markets from six different locations around the UK and reported higher microplastic concentrations in pre-cooked mussels (1.4 particles/g) than in the ones supplied live ( 0.9 particles/g). This suggests that the pre-process of pre-cooked mussels could imply a higher exposure to microplastics coming from the process itself due to insufficient cleaning standards and not necessarily from the environment. Cho et al. (2019) surveyed the microplastic presence in four commercial bivalves from three major cities of South Korea. The mean concentration of microplastics in the four species was $0.15 \pm 0.20$ particles/g and it was estimated that the Korean population intakes 212 particles/person/year from shellfish consumption (Cho et al. 2019). All this evidence shows that trophic transfer of microplastics in aquatic organisms is making a pathway for wastes and contaminants into our diet (Fig. 1).

Although microplastic presence in the marine environment have been widely researched, terrestrial ecosystems have been overlooked. There is little information on microplastic degradation by organisms in the plant's rhizosphere (Wang et al. 2019). However, microplastics in soil could significantly alter plant biomass, tissue elemental 
Fig. 1 A model showing how anthropogenic activity cause microplastics to enter the food web, make a path to our food and, ultimately, our organs

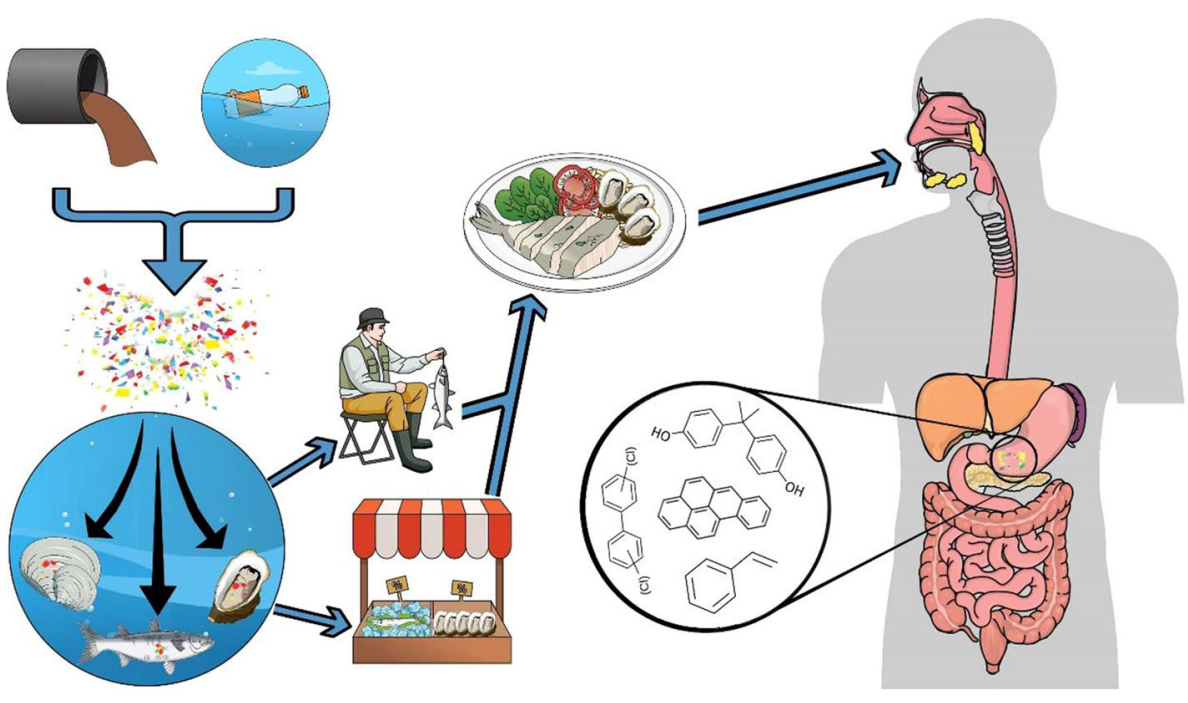

composition, root traits and microbial activities (de Souza Machado et al. 2019). The presence of microplastics haven been evidenced in terrestrial edible snails Helix aperta, Helix aspersa and Helix pomatia (Panebianco et al. 2019), hence contributing to the risk assessment of human exposure to microplastics deriving from food consumption.

Other products consumed as food or used for cooking have been evidenced to be contaminated with microplastics. Microplastics have been found in drinking mineral water (Schymanski et al. 2018), beer, tap water (Kosuth et al. 2018), table salts (Renzi and Blašković 2018), canned food (Karami et al. 2018), and honey and sugar (Liebezeit and Liebezeit 2013). These reports evidence how microplastics have become ubiquitous in human foodstuff and drinks. Low concentration but chronic exposure and intake of microplastics by humans pose a potential threat to human health.

Although some studies are mentioned, there is still knowledge gaps regarding the occurrence of microplastics in foodstuff. There is a lack of standardized methods, monitoring techniques and protocols and no regulatory framework for microplastics in seafood and foodstuff and hence more research is required globally.

\section{Food security}

According to the Food and Agriculture Organization of the United Nations (FAO), "food security is a situation that exists when all people, at all times, have physical, social and economic access to sufficient, safe and nutritious food that meets their dietary needs and food preferences for an active and healthy life" (FAO 2002). The four main pillars of food security are food availability, access, utilization and stability (FAO 2009). Each pillar is equally important for food security. In brief, these pillars are defined by $\mathrm{Mc}$ Carthy et al. (2018) as:

a. Food availability: This pillar refers to having a sufficient quantity of food as a minimum and considers imported or locally produced food. It also takes into account the current food stocks for a particular region and the provision for food aid coming from other countries.

b. Food access: This pillar considers the physical and economic access to food. The main factors within this pillar are the purchasing power of the region and its income level. Another factor to consider is local infrastructure.

c. Food utilization: This pillar encompasses the whole food supply chain and handling. It addresses the production, processing, distribution, retail and household stages of the food supply chain from a hygiene point of view.

d. Food stability: This pillar considers stability of food supply and access, commonly affected by the local political issues, economy and pricing. Also, regional weather pattern changes and climate change cannot be ignored.

The presence of microplastics in seafood compromises the pillars of food availability and utilization. After ingestion, marine organisms cannot break down synthetic polymers through enzymatic activity, meaning microplastics could be retained and not be digested (Guzzetti et al. 2018). This blocks food passages and parts of the intestinal tract (Tourinho et al. 2010), causing reduced feeding and disturbing food digestion in smaller organisms. In microalgae, microplastics have shown to cause a reduction in photosynthetic activity and growth (Sjollema et al. 2016). Ingested microplastics could potentially be adsorbed through the digestive system by translocation (Cole et al. 
2011). Microplastics transfer through the food web (Setälä et al. 2014) and bioaccumulate in more complex organisms. Lu et al. (2016) exposed Danio rerio to micro- and nano-sized microplastics in different concentrations. Microplastics accumulated in gills, liver and gut, causing inflammation, lipid accumulation in the liver and oxidative stress instauration evidenced by the increase in superoxide dismutase and catalase enzymes (Lu et al. 2016). However, the specific effects of microplastic ingestion alone could significantly vary depending on the species and environmental conditions. A bigger concern to the marine biota is the pollutants absorbed or adhered to the microplastics and the leaching of toxic plastic additives. As mentioned before, microplastics are known to interact with heavy metals, PAHs, PCBs, OCPs, PBDEs and pharmaceuticals (Brennecke et al. 2016; Camacho et al. 2019; Fonte et al. 2016; Li et al. 2018c; Rochman et al. 2014). Some of these pollutants are considered toxic, endocrine disruptors, mutagens and biomagnify through trophic transfer (Cole et al. 2011). For example, styrene oligomers (SOs) are low molecular weight compounds derived from polystyrene (Kwon et al. 2017). Kwon et al. (2015) researched the concentration of SOs in sand and seawater from coastal regions around the world. Their results revealed that in Greece, Los Angeles (USA), and Costa Rica, SOs pollution in sand samples reached up to $31,400.0 \mu \mathrm{g} / \mathrm{kg}$, $29,106.8 \mu \mathrm{g} / \mathrm{kg}$, and $26,277.4 \mu \mathrm{g} / \mathrm{kg}$ respectively (Kwon et al. 2015). This indicates alarming levels of pollution with SOs and polystyrene. Considering the synergic interaction with other pollutants, microplastics act as a vector of many potentially toxic xenobiotics. The magnitude of microplastics impact on marine biota from an ecological level is still poorly understood. Nonetheless, microplastic presence and interaction with other organic and inorganic pollutants compromises the health and populations of different marine species. Consequently, the reduction of seafood species populations threatens the pillar of availability, especially in regions dependent on fishing as one of their main sources of food.

The physical properties of plastic materials can make a suitable habitat for diverse microbial communities (Zettler et al. 2013). Biofilms colonizing the plastic surface could become a reservoir for pathogens, faecal indicator organisms and algal bloom species (Keswani et al. 2016), and acting as vector for microorganisms. Recent studies have confirmed the presence of potentially harmful microbes colonizing microplastics from the environment. Kirstein et al. (2016) sampled microplastics from the North and Baltic seas using Neuston nets and later isolated bacterial colonies from the microplastics. Their results confirm the presence of a pathogenic Vibrio parahaemolyticus in various types of polymers (Kirstein et al. 2016). Importantly, ingestion of microplastics colonized by $V$. parahaemolyticus might compromise the survival of shrimp populations in natural waters and hatcheries conditions. Other pathogenic communities colonizing microplastics have been reported (e.g. Virsek et al. 2017). A laboratory research by Harrison et al. (2014) confirmed in a 14-day microcosm experiment that bacteria can colonize low-density polyethylene in little time. Uptaken microplastics by marine organisms are retained through the entire supply chain process, reaching markets and supermarkets (Cho et al. 2019; Li et al. 2018b; Rochman et al. 2015) and ultimately served for consumption. All this evidence suggests that the colonization of microplastics from the environment and its accumulation in seafood exposes humans to pathogenic microbes. Hence, microplastic exposure to environmental microbes compromises the pillar of food utilization.

Although there is a firm connection between microplastic pollution to seafood and the pillars of food availability and utilization, there still little information available to understand up to what extent microplastics could compromise food security. Further research should focus on a macroscale of the impacts of microplastics to make an understanding of the impact to food security.

\section{Exposure and human health}

The main sources of human exposure to microplastics are through inhalation, ingestion and skin contact. Inhaled airborne microplastics come chiefly from synthetic textiles, powdered synthetic rubber tires and city dust (Prata 2018); eating contaminated seafood, other kinds of food and drinking contaminated water are the main pathways to the gastrointestinal tract. Organisms that are eaten completely present a higher risk than eviscerated ones (Carbery et al. 2018). Although the human skin prevents microplastics and other contaminants to pass directly through, some possible entry routes are sweat glands, open skin injuries or hair follicles (Schneider et al. 2009). All three sources of exposure are key to account for the absolute microplastic exposure by humans, yet those coming from seafood and the environment could represent a higher threat due to weathering, leaching of plastics additives, residual monomers (Araujo et al. 2002), longtime interaction with other toxic pollutants (Brennecke et al. 2016; Camacho et al. 2019; Li et al. 2018c; Rochman et al. 2014) and pathogenic microorganisms from the environment (Virsek et al. 2017).

According to Catarino et al. (2017), microplastic ingestion through contaminated mussels is minimal compared to airborne household fibers that fall into our meal. However, estimating microplastic ingestion by humans depends on microplastic content, consumption habits and rates at a local level. For example, Cho et al. (2019) 
estimated that the average Korean ingests 212 particles/ person annually, via the consumption of oysters, mussels, manila clams and scallops, while Van Cauwenberghe and Janssen (2014) calculated that the European minor shellfish consumers ingest around 1800 microplastics annually and top shellfish consumers could ingest up to 11,000 microplastics per year. Chinese consumers could reach a higher annual dietary exposure ( $\mathrm{Li}$ et al. 2015). Indeed, human exposure to microplastics varies significantly in globally every region.

Following microplastic ingestion, particles smaller than $150 \mu \mathrm{m}$ may translocate to the lymph and circulatory system, but absorption is expected in less than $0.3 \%$ of the ingested particles (Barboza et al. 2018). Absorption happens through pinocytosis and vesicular phagocytic processes (Galloway 2015); Microfold cells in the Peyer's patches are the main site of uptake (Van Cauwenberghe and Janssen 2014) for nanoparticles to enter the circulatory system and through the lymphatic system (Galloway 2015). Only $\leq 20 \mu \mathrm{m}$ particles could penetrate into certain organs (Barboza et al. 2018) and the smallest nano-sized plastic particles may access all organs and be transported across cellular membranes (Bouwmeester et al. 2015). Laboratory studies have demonstrated cellular uptake of nanoparticles using different human cell lines (e.g. Forte et al. 2016; Fuchs et al. 2016; Liu et al. 2018; Walczak et al. 2015). The direct effects of nanoparticles are cytotoxicity, inflammation, and production of reactive oxygen species (Elsaesser and Howard 2012). Brown et al. (2001) and Forte et al. (2016) conducted laboratory experiments with polystyrene nanoparticles in A549 lung cells and human gastric adenocarcinoma cells respectively, both showing induced pro-inflammatory responses. Larger polyethylene particles $(0.3-10 \mu \mathrm{m})$ have shown to stimulate the production of cytokines, like IL-6, IL-1 $\beta$, and TNF- $\alpha$ (Green et al. 1998), of which some are inflammatory factors.

One common plastic additive is bisphenol A (BPA), used as an antioxidant or stabilizing material (Yamamoto et al. 2001). BPA can cause endocrine disrupting effects (Halden 2010). It is able to migrate out of polycarbonates, adhering to food or drinks (Calafat et al. 2008), and consequently be ingested by humans. Studies have reported BPA contamination in tuna fish (Munguía-López et al. 2005), meat (Shao et al. 2007), and tap water (Colin et al. 2014), showing how this contaminant could reach highly consumed foods. Meeker et al. (2010) found that BPA concentrations in urine of 167 men were inversely associated with serum levels of inhibin B and estradiol:testosterone ratio, meaning a negative effect on hormones level. BPA could also contribute to obesity development by disturbing alpha and beta receptors in fat tissues (Michalowicz 2014), affecting fat tissue hormones level and interfering with the activity of lipoprotein lipase, aromatase and lipogenesis regulators (Vom Saal et al. 2012). It may induce breast and prostate cancer in mammals, possibly promoting the same types of cancer in humans (Michalowicz 2014). Research have shown that other chemical compounds present in plastics or adhered to microplastics, like residual low molecular weight styrenes, polyvinyl chloride monomer, PAHs, PCBs, OCPs, PBDEs, and pharmaceuticals, including their metabolites, could become carcinogenic, mutagenic and endocrine disruptors after being uptaken.

\section{Conclusion and future research}

Microplastic pollution in marine environments pose a risk to food security and human health. Research has proven the presence of microplastics in seafood and foodstuff around the world, meaning we are always exposed to microplastic ingestion. Nonetheless, little is known about its direct effects on human health. Future research should focus on microplastic monitoring techniques along the supply chain. There is a lack of information on the extent to which food security is affected by microplastic presence. Finally, plastic waste management must be improved, along with microplastic legislation.

\section{References}

Akhbarizadeh R, Moore F, Keshavarzi B (2018) Investigating a probable relationship between microplastics and potentially toxic elements in fish muscles from northeast of Persian Gulf. Environ Pollut 232:154-163. https://doi.org/10.1016/j.envpol. 2017.09.028

Andrady AL (2011) Microplastics in the marine environment. Mar Pollut Bull 62:1596-1605. https://doi.org/10.1016/j.marpolbul. 2011.05.030

Andrady AL (2017) The plastic in microplastics: a review. Mar Pollut Bull 119:12-22. https://doi.org/10.1016/j.marpolbul.2017.01.082

Araujo PHH, Sayer C, Giudici R, Poco JGR (2002) Techniques for reducing residual monomer content in polymers: a review. Polym Eng Sci 42:1442-1468. https://doi.org/10.1002/pen. 11043

Arts MT, Ackman RG, Holub BJ (2001) "Essential fatty acids" in aquatic ecosystems: a crucial link between diet and human health and evolution. Can J Fish Aquat Sci 58:122-137. https://doi.org/ 10.1139/f00-224

Baalkhuyur FM, Bin Dohaish EA, Elhalwagy MEA, Alikunhi NM, AlSuwailem AM, Røstad A, Coker DJ, Berumen ML, Duarte CM (2018) Microplastic in the gastrointestinal tract of fishes along the Saudi Arabian Red Sea coast. Mar Pollut Bull 131:407-415. https://doi.org/10.1016/j.marpolbul.2018.04.040

Barboza LGA, Vethaak AD, Lavorante BRBO, Lundebye AK, Guilhermino L (2018) Marine microplastic debris: an emerging issue for food security, food safety and human health. Mar Pollut Bull 133:336-348. https://doi.org/10.1016/j.marpolbul.2018.05. 047 
Bouwmeester H, Hollman PCH, Peters RJB (2015) Potential health impact of environmentally released micro- and nanoplastics in the human food production chain: experiences from nanotoxicology. Eniron Sci Technol 49:8932-8947. https://doi.org/10. 1021/acs.est.5b01090

Bravo EL, Van Franeker JA, Jansen OE, Brasseur SMJM (2013) Plastic ingestion by harbour seals (Phoca vitulina) in The Netherlands. Mar Pollut Bull 67:200-202. https://doi.org/10. 1016/j.marpolbul.2012.11.035

Brennecke D, Duarte B, Paiva F, Cacador I, Canning-Clode J (2016) Microplastics as vectors for heavy metal contamination from the marine environment. Estuar Coast Shelf Sci 178:189-195. https://doi.org/10.1016/j.ecss.2015.12.003

Brown DM, Wilson MR, MacNee W, Stone V, Donaldson K (2001) Size1314 dependent proinflammatory effects of ultrafine polystyrene particles: a role for 1315 surface area and oxidative stress in the enhanced activity of ultrafines. Toxicol Appl Pharmacol 175:191-199. https://doi.org/10.1006/taap.2001.9240

Browne MA, Galloway T, Thompson R (2009) Microplastic-an emerging contaminant of potential concern? Integr Environ Assess Manag 3:559-561. https://doi.org/10.1002/ieam. 5630030412

Calafat AM, Ye X, Wong LY, Reidy JA (2008) Exposure of the U.S. Population to Bisphenol $\mathrm{A}$ and 4-tertiary-Octylphenol: 2003-2004. Environ Health Perspect 116:39-44. https://doi. org/10.1289/ehp.10753

Camacho M, Herrera A, Gómez M, Acosta-Dacal A, Martínez I, Henríquez-Hernández L, Luzardo OP (2019) Organic pollutants in marine plastic debris from Canary Islands beaches. Sci Total Environ 662:22-31. https://doi.org/10.1016/j.scitotenv.2018.12. 422

Carbery M, O'Connor W, Palanisami T (2018) Trophic transfer of microplastics and mixed contaminants in the marine food web and implications for human health. Environ Int 115:400-409. https://doi.org/10.1016/j.envint.2018.03.007

Catarino AI, Thompson R, Sanderson W, Henry TB (2017) Development and optimization of a standard method for extraction of microplastics in mussels by enzyme digestion of soft tissues. Environ Toxicol 36:947-951. https://doi.org/10.1002/etc.3608

Cho Y, Shim WJ, Jang M, Han GM, Hong SH (2019) Abundance and characteristics of microplastics in market bivalves from South Korea. Environ Pollut 245:1107-1116. https://doi.org/10.1016/j. envpol.2018.11.091

Cole M, Lindeque P, Halsband C, Galloway TS (2011) Microplastics as contaminants in the marine environment: a review. Mar Pollut Bull 62:2588-2597. https://doi.org/10.1016/j.marpolbul.2011.09. 025

Colin A, Bach C, Rosin C, Munoz JF, Dauchy X (2014) Is drinking water a major route of human exposure to alkylphenol and bisphenol contaminants in France? Arch Environ Contam Toxicol 66:86-99. https://doi.org/10.1007/s00244-013-9942-0

de Souza Machado AA, Lau CW, Kloas W, Bergmann J, Bachelier JB, Faltin E, Becker R, Görlich AS, Rillig MC (2019) Microplastics can change soil properties and affect plant performance. Environ Sci Technol 53:6044-6052. https://doi. org/10.1021/acs.est.9b01339

De Witte B, Devriese L, Bekaert K, Hoffman S, Vandermeersch G, Cooreman K, Robbens J (2014) Quality assessment of the blue mussel (Mytilus edulis): comparison between commercial and wild types. Mar Pollut Bull 85:146-155. https://doi.org/10.1016/ j.marpolbul.2014.06.006

Derraik JGB (2002) The pollution of the marine environment by plastic debris: a review. Mar Pollut Bull 44:842-852. https://doi. org/10.1016/S0025-326X(02)00220-5
Elsaesser A, Howard CV (2012) Toxicology of nanoparticles. Adv Drug Deliv Rev 64:129-137. https://doi.org/10.1016/j.addr. 2011.09.001

FAO (2002) The state of food insecurity in the world 2001. Food and Agriculture Organization, Rome

FAO (2009) Declaration of the World Summit on Food security. WSFS 2009/2, Rome

Fonte E, Ferreira P, Guilhermino L (2016) Temperature rise and microplastics interact with the toxicity of the antibiotic cefalexin to juveniles of the common goby (Pomatoschistus microps): post-exposure predatory behaviour, acetylcholinesterase activity and lipid peroxidation. Aquat Toxicol 180:173-185. https://doi. org/10.1016/j.aquatox.2016.09.015

Forte M, Iachetta G, Tussellino M, Carotenuto R, Prisco M, De Falco M, Laforgia V, Valiente S (2016) Polystyrene nanoparticles internalization in human gastric adenocarcinoma cells. Toxicol In Vitro 31:126-136. https://doi.org/10.1016/j.tiv.2015.11.006

Fuchs AK, Syrovets T, Haas KA, Loos C, Musyanovych A, Mailänder V, Landfester K, Simmet T (2016) Carboxyl- and amino-functionalized polystyrene nanoparticles differentially affect the polarization profile of M1 and M2 macrophage subsets. Biomaterials 85:78-87. https://doi.org/10.1016/j.bioma terials.2016.01.064

Galloway TS (2015) Micro- and nano-plastics in human health. In: Bergmann M, Gutow L, Klages M (eds) Marine anthropogenic litter, 1st edn. Springer, London, pp 343-366

GESAMP (2016) Sources, fate and effects of microplastics in the marine environment: part two of a global assessment. In: Kershaw PJ, Rochman CM (eds) IMO/FAO/UNESCO-IOC/ UNIDO/WMO/IAEA/UN/ UNEP/UNDP Joint group of experts on the scientific aspects of marine environmental protection. Rep. Stud. GESAMP No. 93, 220 p

Green TR, Fisher J, Stone M, Wroblewski M, Ingham E (1998) Polyethylene particles of a "critical size" are necessary for the induction of cytokines by macrophages in vitro. Biomaterials 19:2297-2302

Guzzetti E, Sureda A, Tejada S, Faggio C (2018) Microplastic in marine organism: environmental and toxicological effects. Environ Toxicol Pharmacol 64:164-171. https://doi.org/10. 1016/j.etap.2018.10.009

Halden RU (2010) Plastics and health risks. Annu Rev Public Health 31:179-294. https://doi.org/10.1146/annurev.publhealth.012809. 103714

Harrison JP, Schratzberger M, Sapp M, Osborn AM (2014) Rapid bacterial colonization of low-density polyethylene microplastics in coastal sediment microcosms. BMC Microbiol 14:232. https:// doi.org/10.1186/s12866-014-0232-4

Hitchcock JN, Mitrovic SM (2019) Microplastic pollution in estuaries across a gradient of human impact. Environ Pollut 247:457-466. https://doi.org/10.1016/j.envpol.2019.01.069

Karami A, Golieskardi A, Choo CK, Larat V, Karbalaei S, Salamatinia B (2018) Microplastic and mesoplastic contamination in canned sardines and sprats. Sci Total Environ 612:1380-1386. https://doi.org/10.1016/j.scitotenv.2017.09.005

Keswani A, Oliver DM, Gutierrez T, Quilliam RS (2016) Microbial hitchhikers of marine plastic debris: human exposure risks at bathing waters and beach environments. Mar Environ Res 118:10-19. https://doi.org/10.1016/j.marenvres.2016.04.006

Kirstein IV, Kirmizi S, Wichels A, Garin-Fernandez A, Erler R, Löder M, Gerdts G (2016) Dangerous hitchhikers? Evidence for potentially pathogenic Vibrio spp. on microplastic particles. Mar Environ Res 120:1-8. https://doi.org/10.1016/j.marenvres.2016. 07.004

Kosuth M, Mason SA, Wattenberg EV (2018) Anthropogenic contamination of tap water, beer, and sea salt. PLoS ONE 13:e0194970. https://doi.org/10.1371/journal.pone.0194970 
Kumar VE, Ravikumar G, Jeyasanta KI (2018) Occurrence of microplastics in fishes from two landing sites in Tuticorin, South east coast of India. Mar Pollut Bull 135:889-894. https://doi.org/ 10.1016/j.marpolbul.2018.08.023

Kwon BG, Koizumi K, Chung SY, Kodera Y, Kim JO, Saido K (2015) Global styrene oligomers monitoring as new chemical contamination from polystyrene plastic marine pollution. J Hazard Mater 300:359-367. https://doi.org/10.1016/j.jhazmat. 2015.07.039

Kwon BG, Amamiya K, Sato H, Chung SY, Kodera Y, Kim SK, Lee EJ, Saido K (2017) Monitoring of styrene oligomers as indicators of polystyrene plastic pollution in the North-West Pacific Ocean. Chemosphere 180:500-505. https://doi.org/10. 1016/j.chemosphere.2017.04.060

Li J, Yang D, Li L, Jabeen K, Shi H (2015) Microplastics in commercial bivalves from China. Environ Pollut 207:190-195. https://doi.org/10.1016/j.envpol.2015.09.018

Li H, Ma L, Lin L, Ni Z, Xu X, Shi H, Yan Y, Zheng G, Rittschof D (2018a) Microplastics in oysters Saccostrea cucullata along the Pearl River Estuary, China. Environ Pollut 236:619-625. https:// doi.org/10.1016/j.envpol.2018.01.083

Li J, Green C, Reynolds A, Shi H, Rotchell JM (2018b) Microplastics in mussels sampled from coastal waters and supermarkets in the United Kingdom. Environ Pollut 241:35-44. https://doi.org/10. 1016/j.envpol.2018.05.038

Li J, Zhang K, Zhang H (2018c) Adsorption of antibiotics on microplastics. Environ Pollut 237:460-467. https://doi.org/10. 1016/j.envpol.2018.02.050

Liebezeit G, Liebezeit E (2013) Non-pollen particulates in honey and sugar. Food Addit Contam Part A Chem Anal Control Expo Risk Assess 30:2136-2140. https://doi.org/10.1080/19440049.2013. 843025

Lithner D, Larsson A, Dave G (2011) Environmental and health hazard ranking and assessment of plastic polymers based on chemical composition. Sci Total Environ 409:3309-3324. https://doi.org/10.1016/j.scitotenv.2011.04.038

Liu Z, Cai M, Yu P, Chen M, Wu D, Zhang M, Zhao Y (2018) Agedependent survival, stress defense, and AMPK in Daphnia pulex after short-term exposure to a polystyrene nanoplastic. Aquat Toxicol 204:1-8. https://doi.org/10.1016/j.aquatox.2018.08.017

Lu Y, Zhang Y, Deng Y, Jiang W, Zhao Y, Geng J, Ding L, Ren H (2016) Uptake and accumulation of polystyrene microplastics in Zebrafish (Danio rerio) and toxic effects in liver. Environ Sci Technol 50:4054-4060. https://doi.org/10.1021/acs.est.6b00183

Mc Carthy U, Uysal I, Badia-Melis R, Mercier S, O’Donnell C, Ktenioudaki A (2018) Global food security-issues, challenges and technological solutions. Trends Food Sci Technol 77:11-20. https://doi.org/10.1016/j.tifs.2018.05.002

Meeker JD, Calafat AM, Hauser R (2010) Urinary bisphenol A concentrations in relation to serum thyroid and reproductive hormone levels in men from an infertility clinic. Environ Sci Technol 44:1458-1463. https://doi.org/10.1021/es9028292

Michalowicz J (2014) Bisphenol A-sources, toxicity and biotransformation. Environ Toxicol Parmacol 37:738-758. https://doi. org/10.1016/j.etap.2014.02.003

Munguía-López EM, Gerardo-Lugo S, Peralta E, Bolumen S, SotoValdez H (2005) Migration of bisphenol A (BPA) from can coatings into a fatty-food simulant and tuna fish. Food Addit Contam 22:892-898. https://doi.org/10.1080/026520305001 63674

Ory NC, Sobral P, Ferreira JL, Thiel M (2017) Amberstripe scad Decapterus muroadsi (Carangidae) fish ingest blue microplastics resembling their copepod prey along the coast of Rapa Nui (Easter Island) in the South Pacific subtropical gyre. Sci Total Environ 586:430-437. https://doi.org/10.1016/j.scitotenv.2017. 01.175
Panebianco A, Nalbone L, Giarratana F, Ziino G (2019) First discoveries of microplastics in terrestrial snails. Food Control 106:106722. https://doi.org/10.1016/j.foodcont.2019.106722

Pegado TDS, Schmid K, Wilnemiller KO, Chelazzi D, Cincinelli A, Dei L, Giarrizzo T (2018) First evidence of microplastic ingestion by fishes from the Amazon River estuary. Mar Pollut Bull 133:814-821. https://doi.org/10.1016/j.marpolbul.2018.06. 035

Pieniak Z, Verbeke W, Scholderer J (2010) Health-related beliefs and consumer knowledge as determinants of fish consumption. J Hum Nutr Diet 23:480-488. https://doi.org/10.1111/j.1365277X.2010.01045.X

PlasticsEurope (2018) Plastics-the Facts 2017: an analysis of European plastics production, demand and waste data. https:// www.plasticseurope.org/application/files/5715/1717/4180/Plas tics_the_facts_2017_FINAL_for_website_one_page.pdf. Accessed 27 Jan 2019

Prata JC (2018) Airborne microplastics: consequences to human health? Environ Pollut 234:115-126. https://doi.org/10.1016/j. envpol.2017.11.043

Renzi M, Blašković A (2018) Litter \& microplastics features in table salts from marine origin: Italian versus Croatian brands. Mar Pollut Bull 135:62-68. https://doi.org/10.1016/j.marpolbul. 2018.06.065

Rios LM, Moore C, Jones PR (2007) Persistent organic pollutants carried by synthetic polymers in the ocean environment. Mar Pollut Bull 54:1230-1237. https://doi.org/10.1016/j.marpolbul. 2007.03.022

Rochman CM (2015) The complex mixture, fate and toxicity of chemicals associated with plastic debris in the marine environment. In: Bergmann M, Gutow L, Klages M (eds) Marine anthropogenic litter, 1st edn. Springer, London, pp 117-140

Rochman CM, Kurobe T, Flores I, Teh SJ (2014) Early warning signs of endocrine disruption in adult fish from the ingestion of polyethylene with and without sorbed chemical pollutants from the marine environment. Sci Total Environ 493:656-661. https:// doi.org/10.1016/j.scitotenv.2014.06.051

Rochman CM, Tahir A, Williams SL, Baxa DV, Lam R, Miller JT, Teh FC, Werorilangi S, Teh SJ (2015) Anthropogenic debris in seafood: plastic debris and fibers from textiles in fish and bivalves sold for human consumption. Sci Rep 5:14340. https:// doi.org/10.1038/srep14340

Ryan PG, Moore CJ, van Franeker JA, Moloney CL (2009) Monitoring the abundance of plastic debris in the marine environment. Philos Trans R Soc Lond B Biol Sci 364:1999-2012. https://doi.org/10.1098/rstb.2008.0207

Schneider M, Stracke F, Hansen S, Schaefer UF (2009) Nanoparticles and their interactions with the dermal barrier. Dermatoendocrinol 1:197-206

Schymanski D, Goldbeck C, Humpf HU, Fürst P (2018) Analysis of microplastics in water by micro-Raman spectroscopy: release of plastic particles from different packaging into mineral water. Water Res 129:154-162. https://doi.org/10.1016/j.watres.2017. 11.011

Setälä O, Fleming-Lehtinen V, Lehtiniemi M (2014) Ingestion and transfer of microplastic in the planktonic food web. Environ Pollut 185:77-83. https://doi.org/10.1016/j.envpol.2013.10.013

Shao B, Han H, Li D, Ma Y, Tu X, Wu Y (2007) Analysis of alkylphenol and bisphenol $\mathrm{A}$ in meat by accelerated solvent extraction and liquid chromatography with tandem mass spectrometry. Food Chem 105:1236-1241. https://doi.org/10.1016/j. foodchem.2007.02.040

Shim WJ, Hong SH, Eo S (2018) Marine microplastics: abundance, distribution, and composition. In: Zeng EY (ed) Microplastic contamination in aquatic environments-an emerging matter of environmental urgency, 1st edn. Elsevier, Amsterdam, pp 1-26 
Sjollema SB, Redondo-Hasselerharm P, Leslie HA, Kraak MHS, Vethaak AD (2016) Do plastic particles affect microalgal photosynthesis and growth. Aquat Toxicol 170:259-261. https://doi.org/10.1016/j.aquatox.2015.12.002

Su L, Cai H, Kolandhasamy P, Wu C, Rochman CM, Shi H (2018) Using the Asian clam as an indicator of microplastic pollution in freshwater ecosystems. Environ Pollut 234:347-355. https://doi. org/10.1016/j.envpol.2017.11.075

Teng J, Wang Q, Ran W, Wi D, Liu Y, Sun S, Liu H, Cao R, Zhao J (2019) Microplastic in cultured oysters from different coastal areas of China. Sci Total Environ 653:1282-1292. https://doi. org/10.1016/j.scitotenv.2018.11.057

Thompson LA, Darwish WS (2019) Environmental chemical contaminants in food: review of a global problem. J Toxicol 2019:2345283. https://doi.org/10.1155/2019/2345283

Tourinho PS, Ivar do Sul JA, Fillmann G (2010) Is marine debris ingestion still a problem for the coastal marine biota of southern Brazil? Mar Pollut Bull 60:396-401. https://doi.org/10.1016/j. marpolbul.2009.10.013

Van Cauwenberghe L, Janssen CR (2014) Microplastics in bivalves cultured for human consumption. Environ Pollut 193:65-70. https://doi.org/10.1016/j.envpol.2014.06.010

Virsek MK, Lovsin MN, Koren S, Krzan A, Peterlin M (2017) Microplastics as a vector for the transport of the bacterial fish pathogen species Aeromonas salmonicida. Mar Pollut Bull 125:301-309. https://doi.org/10.1016/j.marpolbul.2017.08.024

Vom Saal FS, Nagel SC, Coe BL, Angle BM, Taylor JA (2012) The estrogenic endocrine disrupting chemical bisphenol A (BPA) and obesity. Mol Cell Endocrinol 354:74-84. https://doi.org/10. 1016/j.mce.2012.01.001

Walczak AP, Kramer E, Hendriksen PJ, Helsdingen R, van der Zande M, Rietjens IM, Bouwmeester H (2015) In vitro gastrointestinal digestion increases the translocation of polystyrene nanoparticles in an in vitro intestinal co-culture model. Nanotoxicology 9:886-894. https://doi.org/10.3109/17435390.2014.988664

Wang W, Wang J (2018) Investigation of microplastics in aquatic environments: an overview of the methods used, from field sampling to laboratory analysis. Trends Analyt Chem 108:195-202. https://doi.org/10.1016/j.trac.2018.08.026

Wang J, Liu X, Li Y, Powell T, Wang X, Wang G, Zhang P (2019) Microplastics as contaminants in the soil environment: a minireview. Sci Total Environ 691:848-857. https://doi.org/10.1016/ j.scitotenv.2019.07.209

Yamamoto T, Yasuhara A, Shiraishi H, Nakasugi O (2001) Bisphenol $A$ in hazardous waste landfill leachates. Chemosphere 42:415-418

Zettler ER, Mincer TJ, Amaral-Zettler LA (2013) Life in the "Plastisphere": microbial communities on plastic marine debris. Environ Sci Technol 47:7137-7146. https://doi.org/10.1021/ es401288x

Publisher's Note Springer Nature remains neutral with regard to jurisdictional claims in published maps and institutional affiliations. 